Geophysical Research Abstracts, Vol. 5, 03687, 2003

(C) European Geophysical Society 2003

\title{
GAS TRANSFER VELOCITIES OF CO2 IN THREE EUROPEAN ESTUARIES (RANDERS FJORD, SCHELDT AND THAMES)
}

\author{
A. V. Borges (1), B. Delille (1), L. -S. Schiettecatte (1), F. Gazeau (1), G. Abril (2) \\ and M. Frankignoulle (1) \\ (1) Unité d'Océanographie Chimique, Université de Liège, (2) Département de Géologie et \\ Océanographie, Université de Bordeaux (alberto.borges@ulg.ac.be/Fax:+32-4-3662355)
}

The flux of $\mathrm{CO}_{2}$ across the air-water interface was measured with the floating dome method in three European estuaries with contrasting physical characteristics (Randers Fjord, Scheldt and Thames). From concomitant measurements of the air-water gradient of the partial pressure of $\mathrm{CO}_{2}\left(\mathrm{pCO}_{2}\right)$, the gas transfer velocity of $\mathrm{CO}_{2}$ was computed. A significant linear relationship between the gas transfer velocity of $\mathrm{CO}_{2}$ and wind speed was found for each of the three estuaries. The differences of the constant and the slope between the three relationships are discussed in terms of contribution of tidal currents to water turbulence at the interface and fetch. The contribution of tidal currents to the gas transfer velocity of $\mathrm{CO}_{2}$ is significant in macrotidal estuaries (Scheldt) and negligible in microtidal estuaries (Randers Fjord). Our results strongly suggest that, in estuaries, a simple parameterization of the gas transfer velocity of $\mathrm{CO}_{2}$ as a function of wind speed is site specific. 